\title{
Marco Ferreri: The task of cinema and the end of the world
}

Daniele Rugo, Goldsmiths, University of London

\begin{abstract}
This article identifies Marco Ferreri’s original contribution to cinema as a gesture aimed at exposing the 'end of the world'. This expression should be understood - aside from millenarian connotations - as a reopening of sense in excess of acquired significations. Ferreri supports this gesture through images that deliberately defy conceptual validation, so that his films often move from the meticulous description of ordinary situations to the collapse of meaningful references. In order to contextualize the framework described above, the argument traces Ferreri's trajectory back to neo-realism, highlighting elements of continuity and moments of rupture. In particular, the article highlights how Ferreri delivers the humanism expressed by neo-realism to a world without thought.
\end{abstract}

\section{Keywords}

\author{
Marco Ferreri \\ neo-realism \\ essential images \\ monuments \\ end of the world \\ hope
}

sense 
The world is alive and no living thing has any remedy. That is our fortune. (Bolaño 2011: 20)

According to André Bazin, the humanism expressed by Italian neo-realism amounts to a revolutionary promise. Bazin locates this promise in the acknowledgement by Italian post-war directors that 'the world is, quite simply, before it is something to be condemned' (1971: 21). The reference to the world is not immediately converted into a political sign. For Bazin, in Italian post-war cinema the world becomes the measure of a political statement made by the film. In order for this measure to be effective, something must be left out; the world must survive the force of change exercised on it by the film. At the end of the film, there must still be a world out there, which the former cannot totally encompass, overwhelm or exhaust. The political message is therefore conveyed through the observation of the sense of the world in its saturated distortion. Miracles, redemptions and clemency offer resolutions to such observational work. As C. Zavattini invoked, cinema 'should never look back [...] it should look at life not from the point of view of the plot, but from that of existence' (1952: 14). Bazin's argument could therefore be translated as follows: 'the world is, quite simply, even after it has been condemned'.

Neo-realism would therefore reassert the permanence of the world as a tool to mobilize an emancipatory critique and to convey progressive political claims. Italian critic Adelio Ferrero traces three ideologically constitutive elements at the heart of Italian cinema in the 1940s: 'cinema as contribution to the self-understanding and consolidation of a "new Italy", the discovery of the "wretched" and their demand for justice, the resurfacing of the tradition of realism' (1999: 233). These three elements trigger a 
demand for radical change. The evidence that the world resists this demand for transformation, that things still have to be changed, constitutes the very political force of neo-realism. When Bazin writes ‘tell me if you don't, coming out of an Italian film, feel better, if you don't want to change the order of things' (1971: 22), he is implicitly identifying in the resistance of the order of things a cinematographic device. The sense of the world has remained closed within its present conditions of possibility. One owes to Bazin this formulation of the legacy of neo-realism: that film moves from the world and finally returns to it. The world is left intact; through this friction, something politically relevant will emerge.

For Marco Ferreri, it is precisely this persistence of the world that must be questioned. This incessant questioning structures for him the task of cinema. While adhering in many ways to neo-realism, Ferreri nonetheless elaborates the task of cinema and cinema's political force not in the return to the world, but in the possibility of exposing the world's end. Ferreri supports this gesture through images that deliberately defy conceptual validation, so that his films can often be seen to move from the meticulous description of ordinary situations to the collapse of meaningful references.

\section{The neo-realist moment}

While it is impossible to reduce even Ferreri's early films purely to neo-realism, something of that mode remains at work throughout his career. His first experiences as a film-maker coincide with some exemplary moments of the neo-realist trajectory.

In the late 1950s, together with Riccardo Ghione, Ferreri produced Documento mensile/Monthly Journal (1951), a filmed magazine that, in the authors' words, was 
supposed to be an anthology of neo-realism, including short reportages by the likes of Rossellini, Visconti, Moravia, Guttuso, Levi and Antonioni. Following the relative failure of this experience, Ferreri helped the production of L'Amore in Città/Love in the City (1953), an omnibus film including works by Fellini, Antonioni, Lattuada, Lizzani, Maselli, Risi and Zavattini. While his first two films, produced in Spain, were quickly branded as black humour, Ferreri deliberately resisted the definition, demanding instead to be placed within the neo-realist lineage. In an interview about El Pisito/The Little Apartment (1958), Ferreri says: 'it was a realist story and not black humor [...], I thought I had made a neo-realist film, with comedy and satire, but eminently neo-realist [...], I prefer to be called simply a neo-realist director' (Vigni 1995: 148). As C. Lizzani highlights in a review of the legacy of neo-realism, Ferreri's characters 'are always caught within their material milieu, despite the decisive influence of European culture and its avant-guards' (1999: 103).

Ferreri could, to an extent, be considered a self-conscious neo-realist. As other Italian directors of the time, he begins to see that the heroes of the Resistance - those models that had grown into characters such as Don Pietro and Pina - have by the mid1950s either joined a parasitic and disinterested lower middle class or else have been unable to carry their dreams of freedom and equality any further, to the point of becoming themselves figures of defiance. Since the beginning of his career, Ferreri is aware that the neo-realist aspirations could be easily twisted to promote a vague populism, what F. Fortini called 'that at once generous and ambiguous road that should lead us to socialism' (1957: 158). 
Nonetheless, in order to understand what are the specific elements that Ferreri inherits from neo-realism, it is worth following Bazin in his characterization of the movement. Bazin's analyses constantly return to a number of distinctive modes that characterize performance, setting, photography and narrative. Among the elements that identify neo-realism, Bazin insists on the following: the privilege accorded to life in opposition to techniques of dramatic performance; the detailed exploration and minute analysis of facts and social conditions; the reduction of plastic compositions; the possibility of improvisation embedded in the writing process. Bazin writes: 'Neo-realism is to be defined by a specific relation of means to ends. The pride of place they give to the representation of reality at the expense of the dramatic structures' (Bazin 1971: 87). For Bazin, at the root of neo-realism one finds the disappearance of the story. The action is deprived of its essentiality, so that the films unfold by pure accident, and everything happens by chance. This does not amount to saying that the film is relinquished to a pure reproduction of reality and the chance encounters that this solicits. At the opposite, the recording of reality is never mute: the obvious must be produced in the absence of a story.

The realist paradox, according to which art can never be achieved simply by the suppression of the technical apparatus, is renewed once again in Italian neo-realism. It is through the production of an essential ambiguity that something like realism is attained, as the attempt to separate the singularity of the documented reality from the pre-formed intention of the director. Something of this singular appearance comes to bend the meaning of the film. Bazin writes that 'the director's art lies in the skill with which he compels the event to reveal its meaning, without removing its ambiguity' (1971: 88). De 
Sica and Rossellini achieve realism by reducing the prominence of the narrative. Further on, commenting on the use of ellipsis in Rossellini, Bazin adds: 'it is a lacuna in reality, in the knowledge we have of it, which is by nature limited' (1971: 66). Neo-realism is not simply an approach to cinema; it is a specific type of phenomenology, assumed from a specific ontological position.

Ferreri largely adopts this canon. Up to his very last film he will try to reestablish the material conditions that make room for the kind of freedom typical of post-liberation cinema. Often, Ferreri does so by limiting the set to real apartments (Dillinger $\grave{e}$ morto/Dillinger is Dead, 1968) or small hotel rooms (Diario di un vizio/Diary of a Maniac, 1993). On other occasions, the camera opens its sight onto the large emptiness of deserted beaches (Il Seme dell'Uomo/The Seed of Man, 1969 and again Diary of a Maniac). At other times yet, Ferreri takes over an entire city, but in order to transform it into a sort of hollow margin a simulated backdrop or artificial labyrinth, as the Paris of Touche pas à la femme blanche/Don't Touch the White Woman (1974) or I Love You (1985), the New York of Ciao Maschio/Bye Bye Monkey (1978) and the fascist architecture of Sabaudia in Storia di Piera/The Story of Piera (1983). Given such relations with space and with the set, Ferreri brings to an extreme the so-called biological element, which Bazin evokes in his pages on neo-realism: 'the necessity inherent in the narrative is biological rather than dramatic, it burgeons and grows with all the verisimilitude of life' (1971: 31).

Furthermore, Bazin praises Italian cinema for the delicate intrusions of the camera, for its ability 'to choose at once what is needed and how' (1971: 276). Similarly, Ferreri deploys a cinematographic style often reminiscent of neo-realism: photographic effects 
are kept always at a minimum of expression, even in films like The Seed of Man, where the catastrophic tone seems to demand a special kind of treatment. Photography remains objective in style.

This brief analysis serves to underline how Ferreri remains in many ways within the neo-realist tradition, embracing the ideal of cinema as disclosure of the world. It is precisely how this disclosure is developed that separates him from De Sica or Rossellini. Ferreri builds his distance from neo-realism on the diverging interpretation of this disclosure. It is at this juncture as well that the persistence of the world can be put into question.

\section{Overcoming neo-realism}

Ferreri does not produce simply a reversal or an overcoming of neo-realism; rather, he exacerbates its findings, bringing to a limit the 'appearance of the real'. The overcoming of neo-realism produced by Fellini, for instance, goes in the direction of the supernatural and the symbolic. The figure of this transformation can be identified in the constant presence of the angel. The symbolic is never a resource for Ferreri. The symbol has lost its reference in favour of a procedure that deliberately defies conceptual validation. The possibility for a sign to stand for something else has vanished. On the one hand, all existing symbols have been absorbed by their references, so that the two now form part of the same cluttered space. On the other, the referencing system is undergoing an operation of dismantlement. To present the embryonic stage of this dismantlement is the motive of a large part of Ferreri's films. 
The process of supernaturalization that, according to Bazin, Fellini systematizes in order to overcome neo-realism demands that things find the "ultimate referent, the final measure of being' (Bazin 1971: 89). This kind of transcendence, a poetic reordering of the world in the name of an otherworld, is absent from Ferreri's preoccupations. Ferreri, one could say, knows only the trans of the immanent, its crossing, taking place and internal repositioning. The Fellinian angel is substituted in Ferreri by objects, which become prominent precisely because they do not stand as symbols for anything; they simply signal their own existence, the space they occupy, the function they serve or create and the limited set of actions they accompany or stimulate. The possibility for objects to exist outside their human use is not elaborated symbolically, but as a necessary, if overlooked, reality.

In Ferreri, there is no ultimate sense, as much as there is no principle or ground on which to stand. Ferreri thinks through and shows a world without destination and without thought. In this, he remains profoundly neo-realist, his films confirming the affirmation that 'it is only from the simple appearance of beings and the world that (cinema) knows how to deduce the ideas that it unearths' (Bazin 1971: 65).

For Ferreri, the film should inhabit the very world of resources that it promises to collapse. Common sense, real-life situations and common objects form the central part of his strategy. However, the events of a neo-realist film quickly become a sort of negative resourcefulness. The resources of these events provide for a moment of negation. As with neo-realism, one starts with productive possibilities, with insights into the everyday and with social descriptions treated not in function of narrative teleology, but as autonomous elements. At the same time, though, Ferreri's films proceed by removals and 
eradications: possibilities are turned down one by one and the everyday, from accessible resource, becomes 'what is most difficult to discover' (Blanchot 1993: 238). Ferreri starts from a very close investigation of reality, but this becomes so sharp, so intense, that it emerges as the element to be negated. The comic provocations one witnesses belong to this impulse to negate the resources offered by the organization of sense into shared meanings. Ferreri's films can be seen thus to move from the meticulous description of ordinary situations to the collapse of meaningful references.

It is the drying up of possibilities that drives the film towards its sharpest political comment. That the film should not be recuperated by a common discourse - which makes the vision of the film, both as reception by an audience and as prophecy, a foregone conclusion - produces the surfacing of an 'excess of sense'. Ferreri's central preoccupation is always that one may indeed by way of a film end up without a world, without a sensible set of references, of acquired meaning. The only acceptable strategy can be a reinvention of meaning from unknown resources. That the world should be opened up to uncertain lines and consigned to a self-image yet to be deciphered, this Ferreri makes the task of cinema.

An initial immersion in the world, in the world's immediacy, is brought to confront the world's absence - the fact that the exhaustion of meaningful resources does not offer new resources. The incommensurability that one confronts here shows its own concretion in images that exclude any referential character. One of the many problems faced by critical approaches to Ferreri's films is precisely that his images and visions are often treated as analogies, metaphors or allegories. Most commentators take the manifestations of the incommensurability between immediacy and absence as the work of symbols and 
icons (as if to say: 'he cannot really mean what we see'). Symbols and metaphors are the very figures Ferreri attempts to work against, so to exclude them from the film. In articulating the thought that a world cannot persist, Ferreri proceeds literally. As long as one understands the dotted gun, the ape-woman, the giant Coca-Cola bottle or King Kong's body as metaphors, one runs the risk of pushing Ferreri's films to a territory, that of symbolism or expressionism, they do not belong to. Ferreri's films are not subversive enigmas, neither film à clef, but systems deriving their force from the overlapping of evidences. The level at which they demand to be read is always that of the surface of what is presented. The excess there produced never flows into the enigmatic, the doublesense or the eminently exegetic, but blocks us at the doors of the obvious. The coherence of the film is in its incessant presentation, which quickly obliterates references and interpretation. If the film strikes us, it does so from the reverse side of an accurate metaphor. The image has made room for itself, it has arranged itself in this particular way, its boundaries and its space do not hang on to anything, they simply provoke another image. At any moment in the film, a white space or a blind spot can replace or absorb the image. As someone shouts in Nitrato d'Argento/Nitrate Base (1996) Ferreri's last film - 'it is about time that films start watching their spectators'.

\section{The end of the world}

For Ferreri, the persistence of the world is what is always at stake; he is the filmmaker who more than any other pushes the world towards its end. However, there is nothing millenarian or cataclysmic about this project. Ferreri does not announce to us that the world will necessarily end, such metaphysical propositions stand in stark opposition 
to his work. Ferreri does not locate extinction at the historic conclusion of the world. The extinction of sense does not inhabit an 'other' side of the world; it is to be found in the midst of the world itself. Extinction is of the world; it happens at each moment, and is part of the very constitution of a world. The work of the camera is precisely that of removing the world from its persistency, delimiting a space for the presentation of this loss. The world abandoned to its own persistence is the world Ferreri aims to obliterate, so that its sense can be reopened. Reopening also means resisting the lure to replace one conception of the world with another; it means precisely to do away with the world as ordering or ordered concept.

In the expression 'end of the world', Ferreri always pronounces at once the world's extinction and its aim or intrinsic possibility. It is through a process of extinction that the world finds its possibility. The reduction of the story and the primacy of the physiological one often encounters in Ferreri are only the most explicit devices of a process according to which the world is exposed as not having sense. This process determines 'how the end of the world of sense opens the praxis of the sense of the world' (Nancy 1997: 10). The necessity of this 'end' as the source of knowledge and hope is what Ferreri channels into his films.

\section{The trajectory of the end}

The movement of Ferreri's cinema opens up its own space through a process of horizontal exhaustion. It necessarily exhausts all that it encounters; it leaves nothing untouched, for the tasks of this cinema are the end of the world and the radical reopening of sense. In order for this exhaustion to succeed, Ferreri structures his films around the 
proximity of two moments: a negative resourcefulness unleashes an indeterminate affirmation. The resourcefulness of what is becomes negative, since it offers no room for elaboration outside negation. Because for Ferreri what is has always already reduced itself to an identity, to a saturation of meaning, one must film and expose this internal combustion. The second moment, which follows complete exhaustion, affirms a possibility beyond resources, a possibility whose appraisal can only be announced. This indeterminate affirmation does not become resourceful; it remains, so to speak, a formulation deprived of syntax. There is in Ferreri no guarantee that the sense of the image will illuminate the world. The image announces the possibility for the world to start making sense, again and again, but does not deploy the structure of this sense.

Ferreri has at times been called an apocalyptic film-maker. This is correct, but only inasmuch as one recuperates in the word apocalypse the idea of disclosure or unveiling disclosure (without reassurance) of the sense of the world, rather than dread of imminent catastrophe. The word designates a movement towards evidence, the removal from concealment. An apocalyptic movement is always at stake in Ferreri, but one that runs opposite to announcements of ultimate limits or eschatological preaching: it consists in opening one's eyes to the evidence of a world with neither principle nor celestial guarantor.

Negative resourcefulness and indeterminate affirmation structure Ferreri's thematic choices pointing to dialectical tensions where the insights into the everyday make room for the absence of meaningful references and the consequent suspension of moral and ethical commands. From a formal point of view, Ferreri organizes these two moments 
according to two devices, which are the visual signature of his cinema: monuments and essential images.

\section{The monument}

Ferreri is the historian of the end of the world, as well as its angel. He announces extinction in the midst of the world by turning everything into the mode of the past. The catastrophe is analysed not in terms of prophecy, but of history, as if it had already happened. This history of the future produces the outline of a transformation in the organization of sense that has only just started. Ferreri seems to be looking for ways to affirm that we have to learn to include regress in our own historicity, the development of reason is not limited to progress. There where Ferreri evokes the destruction of civilization, he does so to signal that the reason overseeing civilization is still caught in an understanding of itself as a march towards the completion of sense, sense of the world and of the human. Ferreri's monuments punctuate any positivism with reminders of regression and expose sense to all that is spurious. What is monumental about them is the gathering at once of an overwhelming display of meaning and the complete inwardness and closure of this meaning.

Monuments are to be found in all of Ferreri's films: the body of King Kong lying in front of Manhattan in Bye Bye Monkey, the garden of dead animals in La Grande Bouffe/Blow-out (1973), the giant tree travelling across the high-rise blocks of Palermo in Il Futuro è donna/The Future is Woman (1984) and the city of Sabaudia in The Story of Piera. It is, though, the museum in The Seed of Man that presents the most interesting case. The domestic display assembled by Cino does not just enclose specific objects, it 
becomes a monument itself. The very ideas sustaining the museum are made part of a history. Ferreri seems to explore a paradox: on the one hand, the museum presents us with sense as accumulation of knowledge and on the other it forecloses sense's singular beginning, its future advent.

The paradox of the museum becomes for Ferreri the framework through which he constructs his monuments, an intrinsic articulation of his reflection on the end of the world. At the heart of a museum is a collection, namely, the interruption operated by an organizing principle. At the heart of this principle, though, lies the 'irrational' dispersion of objects in the world. This disorder never stops animating the principle itself. The museum translates dispersion into a concentration that never stops exposing itself to its original disorder. The museum's claim for completeness - redeployment of appearance according to an organizing principle - incorporates the very disorder it claims to overcome. This aporia reveals a series of problems that could lead the museum to the very point of exhaustion. To put it in other words what is at stake is the impossibility for the museum not to depend on the very interruption it exercises. While the museum constitutes itself on and around an organizing principle, this moment of constitution nourishes, as it were, the promise of its disappearance. For Ferreri, this museum becomes itself another experience of a closed sense.

The precursors of Ferreri in literature are not Verga or Vittorini, but Roberto Artl's Seven Madmen (1995) and R. Walser's chimerical 'Spaziergang' (2010). Everything is announced and then transformed into the past by almost hallucinatory translations. Through this operation sense is reopened to its own excess. 'I feel as if I could continue this report on into all incredulity' (Walser 2010: 61). 


\section{The essential image}

The sense that Ferreri wants to reopen then crosses each parcel of singular existence, as well as the relational plurality through which the world expresses itself. The plural articulation of a world nearing its end is assembled into essential images. The essential image can appear at any moment, but its effect is necessarily that of ending the film. One could even say that its force is independent from any other movement the film produces. At the same time, it is crucial that these images are put in relation, almost surrounded, by other movements, by the dispersion and displacement of sense that the film tries to organize or responds to. If cinema for Ferreri is the possibility of responding to the world, as well as the demand that one positions oneself in relation to the excess of the world, then the essential image is Ferreri's most accomplished strategy. The essential image calls for an excess that puts in question everything else - each parcel of sense that the film mobilizes. Some of these essential images are: the floating bottle of CocaCola in The Seed of Man, the dancing hands in Dillinger is Dead, the explosion at Les Halles in Don't Touch the White Woman, Benito walking into the sea with his trousers on at the beginning of Diary of a Maniac.

The attribute 'essential' designates initially two operations: the image cannot be broken down into elements without losing its sense; the image cannot be replaced with any other series of images without the sense of the film changing completely. However, what is most important about the essential image is that it announces an aporia, activating a series of impossible developments. The essential image is stretched between a past sense that has become a simple identity and a future sense that is only just announcing 
itself, so that its evidence cannot become propaedeutic or pedagogical. The kind of evidence that results from the essential image should thus be understood not only as that which, by being under my eyes, conflates the obvious and the obscure, but that according to which 'my eyes and the world are opened together, the first included in the second, which, at the same time, penetrates them' (Nancy 2010: 70). The essential image is without references; through its evidence, the end of the world is opened as the beginning anew of sense.

Through these images, that which has been developed in the film - a particular story, character, style, idea or mythology - is reduced to an agitation of sense, which means - at once and the same time - exhaustion of sense and access to its excess. This is the reason why it should be called essential: it does not respond to a reference, it rather creates one, but one that at present cannot be determined. The essential image communicates with sense only on the level of its reopening, there where something of sense cannot be conveyed into meaning. These images belong to the limit identified by Blanchot: 'when there is nothing, that is where the image finds its condition, but disappears into it $[\ldots]$, what makes it possible is the limit where it ceases' (Blanchot 1999: 417). They are essential because what is given in them is the force of their being distinct; they offer 'an indefinite totality of meaning' (Nancy 2005: 5). The essential image is obvious, everything in it is already played out, its announcement is complete, but its reception is withdrawn. It is precisely this obviousness that makes its reception impossible, because it signals a not yet, the obliteration of any support of signification. As J.-L. Nancy aptly puts it: 'in a single stroke, which is what makes it striking, the image delivers a totality of sense [...], each image is a singular variation on the totality of 
distinct sense - of the sense that does not link together the order of significations' (2005:

12). The essential image operates precisely at the end of the world: what it impresses on us is the opposite of a world of availability. It offers a world that is not yet available, simply given and therefore calling for articulation. Far from being a hierophant or mystagogue, Ferreri does not accompany the spectator to the intuition of a mystery, he does not promise a superior signification, rather through his work one experiences a suspension in excess of signification.

\section{Dillinger: The multi-tasker or the logic of operosity}

Most commentators have hailed Dillinger is Dead as Ferreri's most accomplished film. The reasons supporting such judgements rest on the film's formal precision, the absence of dialogue and the shock it produces (Fofi 1995: 203). The reasons why Dillinger is Dead is particularly relevant for the present discussion lie elsewhere. It is not simply a specific formal or narrative device that makes the film stand alone, but the precision of its procedure. It is here that Ferreri draws his trajectory and deploys his strategies with the greatest force. The acute descriptions of Glauco's daily routine metamorphose into the collapse of sense as a resourceful set of references. The film offers both immersion in the world and its obliteration, announcing the end of the world precisely by exploring, literally, the world's immediacy. It presents the spectator with essential images and monuments, often combining the two. The reflection of Dillinger is Dead condenses, in the most acute form, Ferreri's idea of cinema as the end of the world.

In this film, one finds instances of Ferreri's neo-realism, in particular in the minute description of everyday life and the use of real settings. The apartment where Glauco 
lives is a real apartment in Piazza in Piscinula (Rome), while the kitchen used for the cooking sequences is the real kitchen of actor and frequent collaborator Ugo Tognazzi. The style of the cinematography is extremely simple, with the camera barely moving, minimal lighting design and little decor. However, these moments are counterbalanced by a series of rebuffs. Glauco, who has no name on the screen, is marked since the beginning by a particular kind of refusal. The first and last lines that he speaks read like this: 'I don't want to make these objects anymore'. From then on, Glauco embarks in a series of operations that follow one another through a mixture of contingency and necessity. It is precisely in this state of heightened industriousness and operosity that one can glimpse Glauco's refusal, a touching point between activism and apathy.

At times, this refusal traces Glauco as the outline of a companion for Melville's Bartleby. His passivity moves beyond the intellectual passivity of consumerism, he has opened up to a new state. He seems to belong to the lineage of innocents described by G. Deleuze. This type of character is the producer of a new logic: 'things remain enigmatic yet non-arbitrary: in short, a new logic, but one that grasps the innermost depths of life and death without leading us back to reason' (Deleuze 1998: 82). While in Melville though one has thoughts without images, in Ferreri the opposite is true: one is presented with images without thoughts able to receive them.

The logic that Glauco follows and establishes (precisely in this order: the logic is established thanks to a jerky reiteration) is not a logic that brings us back to reason, quite the opposite it is a logic without reference. Glauco is a man without references, to the point of achieving a very singular kind of comedy. His comical currency lies in his literality (he is literal to the point of not having a proper name). It is in this literality that 
his refusal is concentrated, for it is a refusal that does not follow abstinence or withdrawal (like Bartleby), but a tremendous operosity. His hands move constantly and at some point even take on autonomous life, staging a performance that becomes the most essential image of the film. While the operosity of the one-dimensional man or of the free-timer is destined to recreate the very same logic of labour, that of Glauco detaches him from any sensible reference; it makes sense only by retracing the border of sense.

This refusal as operosity brings up the impulse-images that Deleuze invokes in discussing Ferreri's work (Deleuze 2005: 132). However, more than originary worlds, these impulses refer to the itinerant logic that is established only while it is being followed: an object is picked up, and therefore it must be used; someone (an other) is there, and therefore something - sex or murder - must be done with them. The reason for using the object follows the encounter with its shape and not the other way around. Glauco's silent soliloquy composes the following dogma: I do not need the object, but given that it now finds itself in my hands, I will use it. This literality makes of Glauco a multi-dimensional promise, rather than a one-dimensional man. Glauco is a multi-tasker, bringing neurosis and schizophrenia together, 'an unnatural alliance' (Deleuze 1998: 78).

Contrarily to those strategies that one could name 'imagination-reduced' - Bartleby reduces imagination to a formula, while Beckett's Molloy channels it into the famous series of combinatorial stone-sucking - Glauco makes broad use of his imagination. In order to reduce the world by over-operating it, the multi-tasker has to find always new things to do. Glauco paces around the house incessantly, in order to encounter objects that will impose on him something to do. Imagination is turned inside out; its autonomy 
is relinquished to the object. It is the object that dictates activity and not the activity that calls for the object.

Through a meaningless activism, Glauco reduces the world and its immanent order to zero. He follows the logic of multi-tasking literally: nothing has been done, while at the same time there is nothing left to do. At the end of his trajectory, Glauco has exhausted every possibility; he is out of the world. At the same time, his being outside the world is not a departure; it rather means to feel the world according to its opening. Glauco is without sense; he is the man for whom sense has come to an end, but also the one for whom the sense of the world starts all over again. At the end of the film, Glauco leaves his house by car, dives into the sea and swims to a boat. Here he finds a job as a chef and learns that the boat is travelling to Tahiti. The boat travelling towards a red sun before the frame freezes, an essential image whose meaning can be sought only in vain, announces the form of this 'again'.

\section{The task of cinema and the knowledge of hope}

Ferreri's procedure calls for an inversion, a shift in emphasis: from the mode of stable, durable and consistent sense to what one could call the indeterminate and unachievable. This mode is what now requires adhesion, 'there where this does not find anything to adhere to' (Nancy 2010: 21); nothing but an agitation of sense without appropriation, almost non-sensical, meaningless. Ferreri struggles against a world closed in itself, an aquired sense, an ultimate goal. The extinction of the world is only always the liberation of its sense; it is the exposure of the excess of sense with regard to acquired 
significations. Ferreri's task then is the affirmation of sense under the mode of extinction, sense as the rhapsody of the end of the world.

While Ferreri has often been taken as negating any possibility for hope and change, one can suggest the opposite. Ferreri is a film-maker of hope and promise. He presents on the one hand the dangers of the closure of sense on itself. On the other, he offers the absolute opening of sense to its own agitation as only alternative. The very exposure of this agitation requires an enormous effort, the precision of essential images, but also demands that sense is not once more enclosed within a specific line of action or moral command. Ferreri's obliteration of the world thus produces and is produced from the 'knowledge of hope'. It is this peculiar mode of knowledge that motivates his work. Knowledge of hope should be taken as a twofold expression:

- On the one hand, Ferreri asks: what knowledge is required so that hope could become possible? What knowledge is required to prepare oneself for hope, what does one need to know in order for hope to make sense and for sense to produce hope? The answer is that one must consider the 'end' of the world as a constant exposure of acquired meaning to the excess of sense.

- On the other, he invites a second question: what knowledge will follow from the dream of hope? What kind of knowledge could be adequate to match the final realization of our hopes? The answer is that this knowledge would be incommensurable with any available knowledge and it could never be retrieved from the latter. The knowledge that follows from a reopening of sense would be itself open and would demand to remain so. 
For Ferreri, the task of cinema is that of providing 'the opening and the communication of sense as possible, indeterminate and unachievable' (Nancy 2010: 20) and producing thus an encounter with the end of the world, understood as a constant questioning of to the persistence of what is. Cinema must always run this risk: to open a space where everything becomes possible, but nothing is possible yet. Through cinema, the world should open up its monuments to uncertain lines and be consigned to essential images, whose final meaning cannot be determined. Through this reversal of neo-realist humanism, the revolutionary promise is delivered to a world without thought, a world witnessing the end of overarching directions, opened instead to evidences in excess of acquired significations.

\section{References}

Antonioni, M., Fellini, F.,Lattuada, A., Lizzani, C., Maselli, F., Risi, D., Zavattini, C. (1953) L'Amore in Città/Love in the City, Rome: Faro Film

Artl, R. (1995), The Seven Madmen (trans. N. Caistor), London: Serpent's Tail.

Bazin, A. (1971), What is Cinema? (trans. H.Gray), Berkley and London: University of California Press.

Blanchot, M. (1993), The Infinite Conversation (trans. S. Hanson), Minneapolis: University of Minnesota Press. 
(1999), 'Two versions of the imaginary', in G. Quasha (ed.), The Station Hill

Blanchot Reader. Fiction and Literary Essays (trans. L.Davis), New York: Station Hill, pp. $417-27$.

Bolaño, R. (2011), The Last Interview and Other Conversations (trans. S. Perez), New York: Melville House.

Deleuze, G. (1998), Essays Critical and Clinical (trans. D. Smith and M. Greco), London: Verso.

(2005), Cinema 2: The Time-Image (trans. H. Tomlinson and R. Galeta), London: Continuum.

Ferreri, Marco (1958), El Pisito/The Little Apartment, Madrid: Documento Films. (1968), Dillinger è morto/Dillinger is Dead, Rome: Pegaso Cinematografica. (1969), Il Seme dell'Uomo/The Seed of Man, Rome: Polifilm. (1973), La Grande Bouffe/Blow out. Paris: Films 66 (1974), Touche pas à la femme blanche/Don't Touch the White Woman, Paris: Films 66. 
(1978), Ciao Maschio/Bye Bye Monkey, Rome: 18 Dicembre.

(1983), Storia di Piera/The Story of Piera, Rome: Fasofilm.

(1984), Il futuro è donna/The Future is Woman, Rome: Fasofilm.

(1985), I Love You, Paris: AFC.

(1993), Diario di un vizio/Diary of a Maniac, Rome: SOI.

(1996), Nitrato d'argentoNitrate Base, Paris: Audifilm.

Ferrero, A. (1999), 'La “coscienza di sé”: ideologie e verità del Neorealismo', in L. Micciché (ed.), Il neorealismo cinematografico italiano, Venezia: Marsilio, pp.229-49.

Fofi, G. (1995), 'Dillinger è morto', in S. Parigi (ed.), Marco Ferreri. Il cinema e i film, Venezia: Marsilio, pp.203-04.

Fortini, F. (1957), Dieci Inverni. Contributi ad un discorso socialista, Milan: Feltrinelli.

Lizzani, C. (1999), 'Il neorealismo: quando è finito, quello che resto', in L. Micciché (ed.), Il neorealismo cinematografico italiano, Venezia: Marsilio, pp.98-105. 
Nancy, J.-L. (1997), The Sense of the World (trans. J.Librett), Minneapolis: University of Minnesota Press (2005), The Ground of the Image (trans. J. Fort), Stanford, CA: Stanford University Press.

(2010), L'Adoration (Deconstruction du christianisme 2), Paris: Galilée.

Vigni, F. (1995), 'La Fortuna Critica in Italia', in S. Parigi (ed.), Marco Ferreri. Il cinema e i film, Venezia: Marsilio, pp.121-52.

Walser, R. (2010), 'The walk', in Selected Stories (trans. C.Middleton), New York: New York Review Books, pp. 54-104.

Zavattini, C. (1952), 'Alcune Idee sul Cinema Italiano', Rivista del Cinema Italiano, I:2, pp. 5-19.

\section{Contributor details}

Daniele Rugo is co-founder of InC - Continental Philosophy Research Group (University of London) and currently teaches 'Moving Image' and 'Philosophy and...' at Goldsmiths, University of London. He has published on cinema and philosophy in various publications. His forthcoming book Jean-Luc Nancy and the Thinking of Otherness: Philosophy and Powers of Existence will be published by Continuum in May 2013. 
Contact:

Dr Daniele Rugo, Department of Visual Cultures, Goldsmiths, University of London, New Cross SE14 6NW, UK.

E-mail: $\underline{\text { d.rugo@gold.ac.uk }}$ 